\title{
A rare case of persistent visual aura in a 12 year old girl
}

\author{
P Prabhakar , JC Simpson \\ From The European Headache and Migraine Trust International Congress \\ London, UK. 20-23 September 2012
}

\section{Introduction}

Migraine is a common neurological disorder affecting between $3 \%$ and $10 \%$ of children[1]. In up to $30 \%$ of sufferers [2], the headache is preceded or accompanied by a complex of neurological symptoms known as an aura. When aura symptoms persist beyond 7 days without evidence of infarction, the International Headache Society characterizes the condition as persistent migraine aura without infarction [3].

\section{Purpose/objectives}

Persistent visual aura symptoms are rare, and only two published cases describe the condition in children $[4,5]$. We use this case to exemplify the condition and how it has been managed in our specialist clinic. We highlight the need for further insight to allow effective management in the paediatric population.

\section{Methods}

The case of a 12 year old girl who has experienced persistent visual aura symptoms continuously since May 2010 is described, including the results of investigations and treatment history. The patient's illustration and verbal description of symptoms provides a unique insight into her ordeal.

\section{Results}

Our patient's aura symptoms have so far been resistant to pharmacological therapy.

\section{Conclusion}

Aura persistence in children lasting months is unusual. Our specialist clinic has only seen 2 previous cases, in which the aura lasted less than a week, and resolved with treatment for the migraine. As advances are made in our

\footnotetext{
Great Ormond Street Hospital, UK
}

\section{SpringerOpen $^{\circ}$}

(C) 2013 Prabhakar and Simpson; licensee Springer. This is an Open Access article distributed under the terms of the Creative Commons Attribution License (http://creativecommons.org/licenses/by/2.0), which permits unrestricted use, distribution, and reproduction in any medium, provided the original work is properly cited. pathophysiological understanding, further treatment options may be discovered. Until a proven treatment is identified, it is important that clinicians share their experiences to help guide patient management.

Published: 21 February 2013

\section{References}

1. Barnes NP, et al: Migraine. Arch Dis Child Educ Pract Ed 2005, 90:ep53-ep57.

2. Haan J, et al: Acetazolamide treatment for migraine aura status. NEUROLOGY 2000, 55:1588.

3. The International Classification of Headache Disorders. , 2 2005, 1st rev.

4. Liu GT, et al: Persistent positive visual phenomena in migraine. NEUROLOGY 1995, 45:664-668.

5. Faleiro de Almeida Roldão, et al: Migraine with persistent visual aura: response to furosemide. CLINICS 2009, 64(4):375-6.

doi:10.1186/1129-2377-14-S1-P1

Cite this article as: Prabhakar and Simpson: A rare case of persistent visual aura in a 12 year old girl. The Journal of Headache and Pain 2013 14(Suppl 1):P1.
Submit your manuscript to a SpringerOpen ${ }^{\circ}$ journal and benefit from:

- Convenient online submission

- Rigorous peer review

- Immediate publication on acceptance

- Open access: articles freely available online

- High visibility within the field

Retaining the copyright to your article

Submit your next manuscript at $>$ springeropen.com 